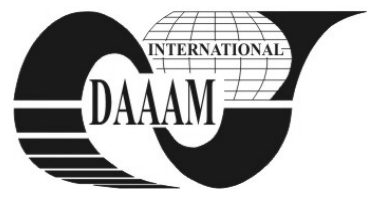

Annals of DAAAM for 2011 \& Proceedings of the 22nd International DAAAM Symposium, Volume 22, No. 1, ISSN 1726-9679 ISBN 978-3-901509-83-4, Editor B. Katalinic, Published by DAAAM International, Vienna, Austria, EU, 2011 Make Harmony between Technology and Nature, and Your Mind will Fly Free as a Bird Annals \& Proceedings of DAAAM International 2011

\title{
THE BASIC CHARACTERISTICS OF SUCCESSFUL BUSINESS STRATEGY
}

\author{
ZAHRADNICKOVA, L[enka] \& VACIK, E[mil]
}

\begin{abstract}
This article shows the need of using an exact treated business strategy for reaching competitive advantage and thus creating value in a firm. The exact standard steps of strategy formulation, implementation and evaluation are to be performed in the whole firm's organism, even at the process' level. But the firm cannot rely only on exact executing of given proceedings. To keep flexibility to respond to environmental development there is necessary to check continuously the correctness of approved business strategy. Beside the "hard" measures, such as financial indicators or values given in firm's technical standards, the "soft" measures gain importance in securing the growth of the firm's performance. Several tools of testing the correctness of business strategy performance are presented in the content of this article
\end{abstract}

Key words: business strategy, strategy formulation, strategy implementation, strategy evaluation, performance

\section{INTRODUCTION}

Strategic competitiveness of firms is achieved when a firm successfully formulates and implements a value-creating strategy. The value-creating strategy means to bring an invincible value to firm's stakeholders. Successful strategy enables the firm to deepen a competitive advantage. A firm gains a competitive advantage when it implements strategy competitors which are unable to imitate.

A strategic management process is the set of commitments, decisions and actions required for a firm so as to achieve strategic competitiveness and earn above-average returns. The tool for it is the business strategy. The standard methodology how to achieve the business strategy is to start with its formulation (to set vision, confirm strategic goals, analyse environment of firm, and build in the risk treatment into the system of strategic planning). A competitive business strategy has to be robust enough to adapt to a change. The second step is a business strategy implementation. It means to mobilize employees and managers to put formulated strategy into action.

Implementation requires personal discipline, commitment and motivation. A successful strategy formulation does not guarantee a successful strategy implementation. Strategy implementation requires such actions as altering sales territories, adding new departments, closing facilities, hiring new employees, changing firm's pricing strategy, developing financial budgets, developing tools of motivation, establishing cost-control procedures, changing advertising strategies, building new facilities training new employees, transferring managers among divisions, building a better information system and others (Hitt et al., 2009).

The rate of effectiveness can be judged only in the case of of a strategy evaluation system in the firm. The strategy evaluation means the set of tools according to a statement whether the business strategy was succefully done.

Matching planned outputs with reached values a principal shareholder's question if the anticipated value has been created will be answered. Generally there are three fundamental business strategy evaluation activities:
- reviewing external and internal risk factors that may destroy a business strategy,

- measuring performance,

- taking corrective actions.

A very important gear how to reach desired goals is to follow the correctness of a business strategy function over the whole phase of strategic management processes. It is necessary to introduce such feedbacks fixed on strategy which preserve the course set by value outcomes declaration the stakeholders expect from.

\section{TOOLS FOR TESTING CORRECTNESS OF A BUSINESS STRATEGY}

Contemporary global economy deals slowly with the impact of economic crises. Firms are seeking new initiatives which could help them to restart performance growth and in this way ensure lasting competitiveness in the branch. It's evident that it is not possible to continue in the same way before crisis. A crisis checked the resistance of firms and their potential risk management and flexibility in creation of postcrises development plans.

Planning determinants changed too - accent is being put on shorter planning periods, more scenarios involving active approaches involving innovation are needed. If there are new trends, new challenges, business strategies must be carried out in accordance with them. New approaches for identification of the weak points of the business strategy system are required. The strategic management has to be tested in its most sensible points (Simons, 2010).

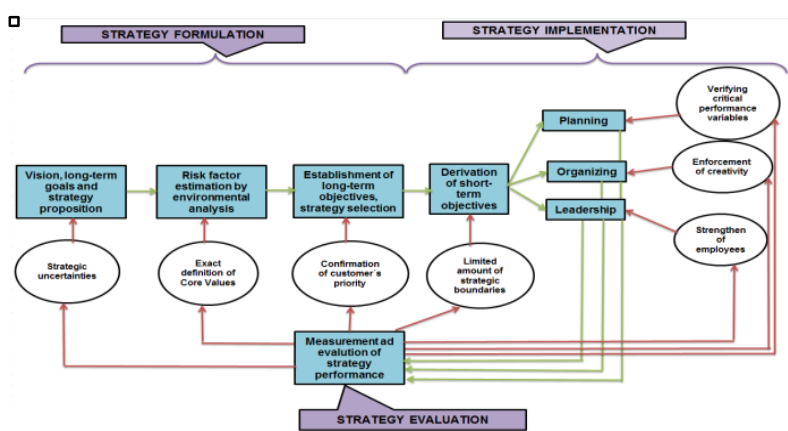

Fig. 1. Strategic management model and tools for its testing

\section{EXPERIENCES OF THE FIRM'S PRACTICE OF STRATEGIC MANAGEMENT}

The basic tool of the company organization and informed management of its future performance is a strategic management. Contemporary strategies can't be based on extended growth, they must emphasize the advantage of differences - this means to focus strategy more on significant details of internal and external art. Multifunctionality of this toolbox is supported by complex tools of performance 
management, e.g. BSC, EFQM and others. Reengineering was also the first process management movement to focus primarily on non-production, white-collar processes such as order management and customer service. It did not emphasize statistical process control or continuous improvement. Many firms we have examined, undertook reengineering projects but most proved to be overly ambitious and difficult to implement. Most recent process management approaches that firms are engaged in are being concentrated around "Six Sigma" methodology. This methodology represents a return to statistical process control.

Some firms combine "Six Sigma" with more radical approaches to processes like "lean techniques". The contemporary philosophy of $\mathrm{ABC} / \mathrm{ABM}$ involves 3 areas which are globally overlapping processes of strategic management operational (Activity based costing $[\mathrm{ABC}]$, tactical (Activity based cost management $[\mathrm{ABCM}]$ and strategic (Activity based management [ABM] (Andersen, 2007). Terminology hasn't been standardized yet. It can be said it is a managerial approach based on managerial costs structure. The influence of economic cycle on performance's indicators hasn't been completely described yet.

According to our experiences the influence of summarising performance indicators based on the Altman's Model has weakened. The firms prefer more indicators based on the CashFlow due to rising emphasis on innovation activities in their strategies. The compliance between the dynamics of change of business environment and the tools of performance management based on strategy is resolved by using process approach today (Vacík \& Zahradníčková, 2011). The contemporary architecture of company processes allows more flexibility however it is more demanding with respect to knowledge potential and empowerment of employees. Some companies apply flexible financial control in key sub-processes. However it remains extremely important how to grasp the formulated strategy, how to distribute it and integrate into company processes and how to ensure their synergies within the framework of existing managerial competencies. The draft of a model of the complex performance management which is based on the formulated strategy is shown at the Fig. 2. It could be valid for firms operating with process management tools. As a methodology for the strategy implementation, the alanced Scorecard has been considered (Jeston \& Nelis, 2008).

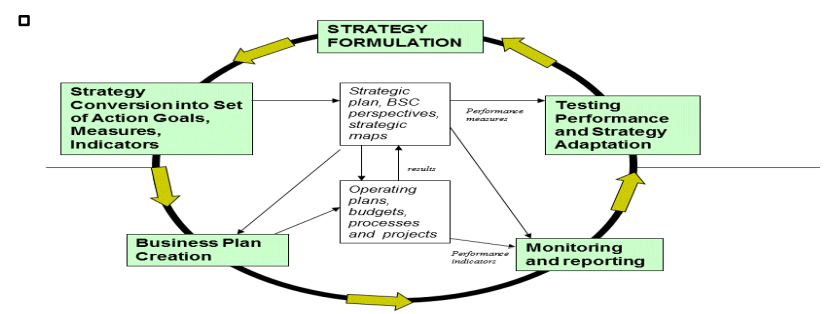

Fig. 2. The Model of the Complex Performance Measurement

\section{WAY OF FURTHER RESEARCH OF THIS TOPIC}

The possibility of further research is to develop contemporary knowledge of performance management into business processes in the way of external impact of macro economical and micro economic factors into business strategy.

Beside enlargement of theoretical background, a possibility for verification of hypothesis created by prediction by use of experiment has been assumed. The proposed research project will be focused on the determination of measuring of flexibility of the accepted strategy, ways and forms of delegation of competencies and responsibilities, deployment of performance metrics in company processes using the tools of the complex performance management, including flexible control of resources and risk management. The prerequisite for this suppose the knowledge of external factors with considerable impact on formulated business strategy as well as process architecture and its full accommodation to this strategy which already was implemented (Simons, 2010). One of the most important outcomes may be designing of mathematical model based on gained research data predicting development of strategic scenarios within the processes. To get to know the value creating elements in the processes there will be possibility to set effective tools for controlling and management of process performance.

\section{CONCLUSION}

For the performance potential of the firm it is significant to become a feature on process effectiveness, seeking, drafting and management of correspondence between strategy, resources and organization in the firms. There is a need to remake the organizations of today into more adaptive, agile and focused organizations. The compliance between the dynamics of change of business environment and the tools of performance management based on strategy is today resolved using the process approach. It's also apparent that process management has become more developing and synthetic too.

The influence of traditional performance indicators based on profit ratio such as ROE or ROA has weakened. The need of incorporating the risk into performance prediction, concerning the development not only of internal environment, but also the impact of external forces, has preferred Value Based Management philosophy. Indicators based on economical profit creation enable to get strategy into business processes. The contemporary approach of ABM correlates with this needs creating a system of Complex Performance Measurement.

The flexible architecture of company processes allows developing knowledge of performance management into business processes. Performance goals formulated in business strategy depend on the impact of macro economical and micro economic factors. Uncertainty of the right future prediction of them creates a space for simulation of strategic scenarios within the processes. The strategy cannot be successful without creating the space for change. Watching development outside the firm, learn trends and evaluate the reality stays the basic managerial facility, which based on professional experiences probably remaining the key success factors of the firm's competiveness.

\section{REFERENCES}

Andersen, B. Business Process Improvement Toolbox (2007). ASQ Quality Press, $2^{\text {th }}$ Edition, ISBN 978-0-87389-719-8, Milwaukee

Hitt, M. A.; Ireland, R. D. \&Hoskisson, R., E. (2009). Strategic Management, Centage Learning, $9^{\text {th }}$ Edition, ISBN 978-0538-75313-5, Canada

Jeston, J. \& Nelis, J. (2008). Business Process Management, Oxford: Elsevier, $2^{\text {th }}$ Edition, ISBN 978-0-75-0686563,Oxford

Simons, R. Seven Strategy Questions: A Simple Approach for Better Execution (2010). Harvard Business Press, $1^{\text {th }}$ Edition, ISBN 978-0-75-068656-3

Vacík, E. \&Zahradníčková, L. Process Performance - a Significant Tool of Competitiveness of Enterprises in Contemporary Era, Proceedings of the $10^{\text {th }}$ International Conference LEF 2001, $19^{\text {th }}-20^{\text {th }}$ September 201, Czech Republic, ISBN:978-80-7372-755-0, pp. 547-556, Technical University of Liberec, Liberec 